\title{
DİJITAL OYUNLARA "OYUN TÜRÜ" YAKLAŞIMLARININ SORUNLARI: "PLATFORM OYUNLARI" TÜRÜ ÖRNEĞİ
}

\author{
Kerem Yavuz Demirbaş
}

\section{ÖZET}

Dijital oyunlar popüler anlamda "aksiyon oyunları", "gündelik oyunlar" ve "sanat oyunları" gibi türsel kategoriler altına yerleştirilmekte ve bu tür ifadeleri ile belirli bir oyuncu kitlesi oyunlara yönlendirilmektedir. Ancak akademik çalışmalar açısından bu ve benzeri "tür yaklaşımları" sorunlar ortaya koymaktadır. Oyunların incelenmesinde oyun biçimi ve anlatı açısından daha sağlıklı bir tür yaklaşımına ihtiyaç duyulmaktadır. Bu doğrultuda varolan tür yaklaşımları eleştirel olarak incelenecek ve oyun araştırmalarında popüler oyun türlerine yanıt olarak ortaya atılmış tür analizlerinin yeterliliği "platform oyunları" türü örneğine bakılarak değerlendirilecektir.

Anahtar Kelimeler: Dijital oyunlar, oyun türleri, platform oyunları, oyun araştırmaları

\section{PROBLEMS OF GENRE-BASED APPROACHES TO DIGITAL GAMES: THE CASE OF PLATFORM GAMES GENRE}

\begin{abstract}
Digital games are categorized in different genres such as "action games", "casual games", "art-games" etc. which makes it easy to direct the right target gamer auidence to the right digital games. But from the perspective of game studies, using these genre conventions is problematic. A genre categorization based on game form and narrative is needed for a critical analysis of games. This paper will elaborate on existing genre approaches in game studies, which are offered as critical alternatives to popular genre conventions. Their validity will be analyzed with selected games from "platform games" genre.

Keywords: Digital games, game genres, platform games, game studies

\section{Gírìş}

Dijital oyunlar, bilgisayarda oynanan ilk oyunlardan biri olan Spacewar'un MIT laboratuvarlarında yapıldığı 1960 yılından beri (Malliet ve Meyer 2005: 25) yaygınlık anlamında epeyce yol kat etmiş, sinema ve televizyon ile birlikte çağımızın en önemli iletişim araçlarından biri konumuna yükselmiştir (Bronkhorst 2012). Dijital oyunlar konusundaki araştırmalar ise 2000'li yılların başından itibaren artan bir ilgiyle disiplinler arası nitelikte sürdürülmektedir (Aarseth 2001). Oyun araştırmaları literatürü başta iletişim bilimleri olmak üzere, eğitim bilimleri, enformatik, sanat ve tasarım gibi disiplinlerdeki araştırmacıların çalışmalarıyla zenginleşmektedir. İletişim bilimleri alanında dijital oyunları konu alan çalışmalarda dijital oyunların iletişim aracı olarak tanımlanması, oyunun medya olarak özellikleri, oyuncu kültürü gibi konularda tartışmalar sürmektedir.
\end{abstract}

*Arş. Gör. Dr., Marmara Üniversitesi İletişim Fakültesi 
İletişim bilimleri alanında yapılan çalışmalarda ve genel olarak sosyal bilimlerde, dijital oyunlar tür yaklaşımları içinde ele alınırken endüstri ve oyuncular tarafından belirlenmiş, bilimsel nitelik taşımayan oyun türü kategorilerinin kullanılmakta olduğunu görmekteyiz (Karaaslan 2015: 810; İnal ve Kiraz 2008: 533; Çakır 2013: 146). Bu durum çalışmaların geçerliliği noktasında soru işaretleri ortaya çıkarmaktadır. Örneğin bilgisayar oyunları ve şiddet ilişkisini ele alan çalışmalarda (Akgündüz ve ark. 2006: 171) örneklemin var olan tür kategorileri içinde belirlenmesi, oyunlardaki şiddet öğesini tema ve öykü düzeyine indirgeyerek etkileşimli, oyunsal özellikler ile anlatı ilişkisinin tartışmaya açılabileceği çok sayıda örneği dışarıda bırakma potansiyeli taşımaktadır.

Oyun endüstrisi içinde, popüler oyun dergilerindeki oyun tanıtımlarında ve oyuncuların ifadelerinde oyunlar, "macera", "strateji", "spor" gibi çeşitli türler altında gruplandırılarak ele alınmaktadır (1). Kullanılmakta olan tür kategorileri incelendiğinde, tüketici olarak oyuncunun satın alma konusunda bilgi edinmesine yönelik oluşturuldukları gözlemlenmektedir. Ancak kategorilerin içine aldıkları oyunların hangi özelliklerini dikkate alarak oyunun türünü belirledikleri pek de açık değildir. Oyunları sınıflandırmak için anlatı veya etkileşimin nasıl yer aldığına yönelik sistematik bir yaklaşımın sonucu olarak ortaya çıkmamışlardır.

Endüstri ve oyuncuların kullandığı "3 boyutlu", "aksiyon", "kitlesel çevrimiçi", "platform" ve "eğitim" gibi oyun türü sınıflandırmaları oyunların aslında farklı başlıklar altında ele alınması gereken özelliklerini ifade etmektedirler. Örneğin "3B" (3 boyutlu) ifadesi (2) oyunun görsel uzamını ifade ederken, "aksiyon" içerikle ilişkilidir. "MMO" (kitlesel çevrimiçi oyunlar) (3) kısmen oyunun oyuncu sayısını kısmen de oyunun oynanışını (gameplay) (4) ifade ederken, "platform" oyun mekanikleri ve oyun dünyasına ilişkindir. "Eğitim oyunları" (5) ise amaç ve içeriğe dair bir kategoridir. "FPS" (birinci şahıs gözünden aksiyon oyunları) oyuncunun görüş açısını ifade ederken, "gerçek zamanlı strateji" (real-time strategy) oyunda zamanın nasıl işlediğini ve oynama biçimini belirtmektedir. "Macera" (adventure) türü, oyunun öyküsünün nasıl bir oyun biçimiyle işlendiğini anlatmaktadır. "RPG" (Rol yapma oyunları) türü ise oyunda öykünün ve diyalogların ne oranda var olduğunu ve oyunun türe özgü oynanışını (gameplay) düşündürecektir.

Tablo 1. Popüler Tür Adlandırmaları ve İşaret Ettikleri Nitelikler

\begin{tabular}{|l|l|}
\hline Oyun Türü & Türü Belirleyen Özellik \\
\hline 3 Boyutlu oyunlar & Oyun dünyasının niteliği \\
\hline Kitlesel çevrimiçi oyunlar (MMO) & Oyuncu sayısı ve oynanış \\
\hline Platform oyunları & Oyun mekanizmaları ve oyun dünyası \\
\hline Birinci şahıs aksiyon (FPS) oyunları & Kamera açıSı, tema \\
\hline Gerçek zamanlı strateji oyunları & Zamanın işleyişi ve oynanış \\
\hline Macera oyunları & Oyunda anlatının işleniş biçimi \\
\hline
\end{tabular}


İletişim bilimleri alanındaki akademik çalışmalara da girmiş olan bu tür yaklaşımı sağlıklı bir sınıflandırma sunmamaktadır. Örneğin "RPG" (rol yapma oyunlari) türünden aksiyon öğesini tamamen kaldıracak olursak elimizde "macera" türüne benzer oyunlar kalır. Ama "macera" oyunlarına aksiyon öğesi eklendiği örnekler "aksiyon macera" (action adventure) içinde ele alınmaktadır. Bu doğrultuda "rol yapma oyunları" türü ve "aksiyon macera" türü arasındaki farkı basitçe oyunun tema veya öykü temelindeki tür adlandırmalarıyla ifade etmek mümkün olmamaktadır (6). Aslında bu iki örnek tür adlandırmasını belirleyen öğeler, oynanış (gameplay) olarak adlandırılan, oyunların etkileşimi de içine alan yapısal nitelikleridir. Kullanılmakta olan popüler tür tanımlamaları oynanış, tema ve oyun dünyası ile ilgili nitelikleri karışık olarak içerdiğinden sistematik bir sınıflandırma imkânı sunmamaktadır.

Oyun türlerine dair bu kategorilerin birbiriyle kesişiyor, bir oyunun çok sayıda farklı kategoride ele alınabiliyor olmasının temel nedeni türleri oluşturan temel prensiplerin keyfi olmasıdır. Popüler tür ifadeleri zaman içinde oyuncuların ve oyun üreticilerinin arasında pratik ve fonksiyonel olarak şekillenmiştir. Başka bir deyişle bunlar tüketime yönelik kategorilerdir ve bilimsel bir analiz için kullanış11 değildirler. (Aarseth ve ark. 2003: 48)

Bu çalışmada, oyunlarda tür sorunu ve iletişim bilimleri içindeki oyun çalışmalarında özel olarak oyun türüne eğilen yaklaşımlar platform türü örneği üzerinden ele alınacaktır. İncelenecek oyunlar platform türü altında değerlendirilmektedir, ancak oyunların oyun mekanikleri, oynanış biçimi ve anlatıları bağlamında nasıl bir türsel kategoriye yerleştirilebileceklerini belirlemek için detaylı bir incelemeye ihtiyaç duyulmaktadır. Bu doğrultuda örnek oyunlar ele alınıp, farklı yönleri ortaya konulurken oyun araştırmalarında var olan tür yaklaşımlarının geçerliliği de değerlendirilecektir.

\section{PLATFORM OYUNLARI TÜRÜ}

Platform oyunları, ana karakterin iki boyutlu veya üç boyutlu grafiklerle kurulmuş oyun dünyasında farklı yüksekliklerdeki platformlar arasında hareket ettirilmesi, ilerletilmesine dayanan bir oyun türüdür (Wolf 2001: 128). İlk oyun konsollarından itibaren popüler olan bu türün en bilinen örneği Super Mario (1985)'dur.

Yüksek işlemci gücü sunan bilgisayar donanımları ve buna uygun olarak gelişen oyun teknolojileri ile görsel anlamda gerçekçi oyunların yaygınlaşması platform türünün yıllar içinde görünürlüğünü yitirmesine neden olmuştur. Ancak görece sınırlı işlemci gücüne sahip mobil teknolojilerin kullanımının artması ve bu cihazlara yönelik oyunların dağıtımı ve üretimi için sunulan olanaklar (7) platform oyunlarının yeniden popülerleşmesini sağlamıştır. İki boyutlu platform oyunları tür olarak mobil cihazların donanım sınırlılıklarıyla uyumlu bir biçimde düşük 
işlemci gücü gerektirmektedir. İnternette yeni oyun dağıtım kanallarının ortaya çıkması da platform oyunlarına alan açılmasında önemli bir eşiktir (8).

Platform oyunları düşük bütçelerle ve kısa sürede üretilebilmektedir. Bu imkân bazı yeni iki boyutlu oyun motorlarının geliştirilmesi ile yenilikçi bazı fikirlerin uygulanmasını da olanaklı kılmıştır. Crayon Physics (2008) oyunu ile birlikte ekrana çizilen şekillerin oyun dünyasına fiziksel nesneler olarak dahil olması veya Braid (2008) oyununda zamanın ileri veya geri alınabilmesi örnek olarak verilebilir. Sadece biçimsel olarak değil, yetişkin kullanıcılara yönelik olarak daha derinlikli öykülerin işlenmesi ile içerik olarak da platform oyunlarında yeniliklere rastlanmaktadır. Hem Crayon Physics (2008), hem de Braid (2008) yenilikçi ve deneysel oyunlara alan açan Bağımsız Oyun Festivali'nde (9) ödül kazanmış oyunlardir.

Bu çalışmada platform oyun türü içinde ele alınabilecek dört oyun tür yaklaşımları çerçevesinde incelenecektir: The Company of Myself (2009), Loved (2010), ImmorTall (2010) ve Time Kufc (2009). Ele alınacak oyunların hepsi çevrimiçi oyun sitelerinde yer almaktadır. Oyunlar Adobe Flash ve Adobe Director yazılımları ile üretilmiştir. Kongregate (10) ve Newgrounds (11) gibi "çevrimiçi oyun siteleri" aracılığıyla kullanıcılara sunulmaktadır. Örnek oyunlar bu sitelerde platform türü altında sınıflandırılmıştır. Oyunlar; bağımsız oyun tasarımcıları, oyun takımları veya grafik sanatçıları tarafından üretilmiştir. Her oyun kendi açısından yenilikçi ve yaratıcı öğeler içermektedir. Örnek aldığımız platform oyunları tema olarak aşk, dostluk, feda, kişilik bölünmesi, suçluluk duygusu veya savaş gibi konulara temas etmektedir.

\section{TÜR YAKLAŞIMLARI BAĞLAMINDA PLATFORM OYUNLARI}

Bu çalışmada örnek olarak alınan dört platform oyunu, Adobe Flash yazılımı kullanılarak üretilmiş olmakla birlikte, bunları bazı çevrimiçi sitelerde yer aldıkları haliyle "Flash oyunları" türü altında sınıflandırmak hatalı olacaktır. "Flash oyunları", oyunların "Adobe Flash" (12) yazılımıyla üretildiklerini, yani teknik olarak nasıl yapıldıklarını açıklasa da oyunların ne içeriğine ne oynanışına dair bir şey söylememektedir. Adobe Flash ile birçok farklı türde oynanış (gameplay) ve içeriğe sahip oyunun üretilebilmesi imkânı bulunmaktadır. Flash ile yapılmış üç boyutlu yarış oyunlarından macera türü altında ele alınan oyunlara kadar çeşitli örneklere rastlanmaktadır. Ayrıca Flash oyunların bulunduğu oyun sitelerinde Java programlama dili veya Unity oyun motoru (13) (game engine) ile üretilmiş oyunlar da yer almaktadır. Özellikle Unity oyun motorunun internet tarayıcı eklentisinin geliştirilmesi ve bu platformun bilinirlik kazanmasından sonra online oyun sitelerinde Unity oyunlarını görmek daha olağan hale gelmiştir. Oyuncu açısından olduğu kadar araştırmacılar açısından da bu teknik farklılıklar oyunun niteliğine dair çok az şey söylemektedir. 
Dijital Oyunlara "Oyun Türü” Yaklaşımlarının Sorunları...

Juul (2010: 8), özellikle internet tarayıcıdan veya Facebook'tan oynanan bu tür oyunları "gündelik oyunlar" (casual games) (14) ve bu oyunları oynayan oyuncuları da "gündelik oyuncular" (casual player) olarak adlandırmaktadır. Juul (2010: 8)'e göre kabul gördüğü haliyle "gündelik oyuncu", olumlu ve rahatsız etmeyen kurgular tercih eden, en fazla birkaç oyun oynamış, oyunlara fazla zaman ve kaynak ayırmak istemeyen, zor oyunları sevmeyen oyuncudur. Flash oyunların bulunduğu sitelerin, internet bağlantısı olan düşük donanımlı bilgisayarlarda oynanabilir kısa ve basit oyunlar içermelerinden dolayı, "gündelik oyuncular" için cazip oyun mekânları olduğu söylenebilir. Bu doğrultuda bu sitelerin "gündelik oyunlar" içermesini beklemek mantıksız olmayacaktır.

“Gündelik" oyun sitelerinde bulunsalar da ele aldığımız oyunlar Juul(2010: 8)'ün tanımlandığı haliyle bu kategoriye uymamaktadır. Immortall, eleştirel ve trajik bir konuya sahiptir. Loved "gündelik" oyunların tam zıddı şekilde nahoş bir konu ve oynanışa sahiptir. The Company of Myself de öykü olarak pek de iç ferahlatıcı sayılamaz ve oynaması nispeten zor bir platform oyunudur. Time Kufc ise içlerinden oynanışı en zor olanıdır ve "gündelik oyun" olduğu söylenemez.

Ele alınan oyunlar "gündelik oyunlar" değildir, ancak "gündelik" türü oyuncuları belirlemek için de kullanılabilir, bir "gündelik oyuncu" profilinden bahsedilmesi de mümkündür. Ancak, oyuncuların yorumları ve ele alınan oyunların oynanma sayıları incelendiğinde oyuncuların oyun seçerken pek de "gündelik" düşünmedikleri ortaya çıkmaktadır. Oyuncular yorumlarında (Kongregate 2014) bu oyunları oynarken ve oynadıktan sonra hayatlarına dair ciddi meseleleri düşündüklerini, oyunların ele aldıkları konuları etkileyici, üzücü veya trajik bulduklarını ve bu yüzden oyunları sevdiklerini belirtmektedir. "Gündelik" oyuncular sahip oldukları kısa vakitte, fazla ciddiye almadan, öyküsü nahoş olmayan ve kolay oyunları tercih eden değil, oyunlarla derin duygusal bağlar kuran ve oynadıkları oyunla oyun içinde ve dışında fiziksel ve düşünsel olarak ilişkisini daha güçlü kuran insanlar olarak da görülebilir.

Tablo 2. Örnek Platform Oyunlarının Oynanma Sayıları

\begin{tabular}{|cc|}
\hline Oyun Adi & Oynanma Sayıs \\
The Company of Myself & $5,264,570$ \\
Loved & $1,500,362$ \\
Immortall & 606,921 \\
Time Kufc & 747,173 \\
\hline
\end{tabular}

Kaynak: Kongregate oyun sitesi, www.kongregate.com, Erişim tarihi: 13.11.2014

Oyunlar mı gündelik, oyuncular mı, yoksa dağıtım kanalları mı? Burada en mantıklı açıklama oyunun platformu ve dağıtım kanallarının, yani aslında endüstri- 
nin yaklaşım tarzının "gündelik" olarak etiketlediği bir tüketiciye yönelmiş olduğudur. Juul (2010: 8)'ün üzerinde durduğu "gündelik" kategorisi oyunların kendisini analiz etmeye yönelmiş bilimsel bir kategori değil, daha ziyade endüstrinin üretimi tarafından şekillendirilmiş fonksiyonel bir kategoridir. Bu yüzden "gündelik oyunlar" türü de "Flash oyunlar" türü gibi oyun anlatısı veya oyun biçimine dair ciddi yaklaşımlar açısından terk edilmelidir.

\section{3. "SANAT OYUNLARI" TÜRÜ}

Ele aldığımız oyunlar tasarım ve öyküleri nedeniyle "sanat oyunları" (Parker 2013: 41; Demirbaş 2008: 18) kategorisi içinde de ele alınmaktadır. The Company of Myself te yönlendirdiğimiz oyun karakterinin iç sesi (15) edebi çağrışımlar uyandırmaktadır. ImmorTall'un öyküsü ve oyunun atmosferi, renkler ve oyunda yönlendirilen karakter gibi öğeler arasındaki uyum estetik bir duyuma hitap etmektedir. Ancak bu izlenimlerden kolayca sonuca atlamadan önce, sanat oyunlarının ne ifade ettiğine veya bu çalışmanın yaklaşımı açısından ne sunduğuna bakılmalidir.

"Sanat oyunları" türü tıpkı sinemada "sanat filmi" tür adlandırması gibi yüzeysel bir yaklaşım sunmaktadır ve tam olarak neyin ifade edildiği de belirsizdir. (Tüker 2014: 192) Oyunun ne zaman sanat olduğu, neyin sanatsal olduğu konusunda tartışmalar sürmektedir. Oyunları "sanatsal" olarak etiketlemek ise yine sanat piyasasına yönelik pazarlanmasına yönelik bir yaklaşım olarak da okunabilir.

Oyunda "sanatsal" olan şeyin ne olduğu farklı şekillerde cevaplanacağından, farklı alt kategorileri de gerekli kılar. Oyundaki mekânların mimarisi, oyun grafikleri, oyunun bölüm arası videoları, oyun nesnelerinin tasarımı, oyunun anlatıs1 ve benzerleri için birbirinden farklı "estetik" veya "artistik" kategoriler türetilebilir. Sonuçta oyunun oynanış biçimi (gameplay) olarak ne içerdiğine dair hiçbir fikir elde edilemeyecektir. (16)

Ayrıca bir başka sorun da geniş tüketici kitlelerine yönelmiş endüstrinin başarılı büyük bütçeli yapımlarının neden sanatsal olarak değerlendirilmediği noktasındadır. Üretilen oyunlar oyun biçimi olarak türlerinden bağımsız olarak sanat içeriği taşıyabilir veya taşımayabilirler.

Ele alınan platform oyunlarının bulunduğu sitelerin yöneticileri (Armorgames 2014), oyunları "sanatsal oyunlar" değil de "puzzle" veya "platform" kategorileri altına koyarak daha geniş bir oyuncu kitlesiyle buluşmasını sağlamıştır. Bu bilinçli veya bilinçsiz tercihin fonksiyonel değeri bir kenara bırakılsa da, oyunları anlamı muğlâk bir "sanat oyunu" türü altında ele almanın oyunların oynanışını dikkate alan bir analize katkı sunmadığı açıktır. 
Dijital Oyunlara “Oyun Türü” Yaklaşımlarının Sorunları...

\section{ETKILLEŞIM TEMELINDE TÜRLER VE OYUN MEKANIKLERİ}

Oyun araştırmaları açısından, oyunları oynanışına (gameplay) göre kategorize etmek için etkileşimi incelemek daha geçerli bir yaklaşım olma potansiyeli taşımaktadır. Oynanışın temel unsurlarından olan oyun mekanikleri, oyuncunun oyunda temel olarak ne yaptığını ifade etmektedir (Schell 2008: 41). Bu doğrultuda bir sinıflandırma olarak Wolf'un (2001: 113) kısmen oyun mekaniklerine göre yapmış olduğu kategorizasyon örnek verilebilir. Wolf (2001: 117-134) oyuncunun veya oyun karakterinin oyundaki eylemlerine göre çok sayıda kategori önermektedir: Yakalama, toplama, atlatma, kaçış, engelli parkur, platform, bulmaca, sorucevap, labirent vb. Wolf (2001: 116)'a göre bu ifadelerden birkaçı birden oyunun türünü ifade etmek için kullanılabilir. Yani bir oyun yakalama, kaçış ve sorucevap olabilir. Bu yaklaşımda türü belirleyecek oyun öğelerinin seçilmesi etkileşim biçimine göre gerçekleştirilmeye çalışılmaktadır.

Oyunun oynanış biçimini daha iyi ifade eden terimler kullanılması itibariyle bu tür bir sınıflandırma görünürde daha verimli olma potansiyeli taşımaktadır. Ancak birbiriyle örtüşen kategoriler yaklaşımı zayıflatmaktadır. İkinci olarak bu terimlerin çoğu oyun mekaniklerini ifade ettiğinden oyun türünün belirlenmesinde eksik bırakılan yönler kalmaktadır. Öne sürülen kategorilerin bir bölümü mekâna ve içeriğe dair olup diğer terimlerle birlikte ayn düzlemde ele alındığından yaklaşım netliğini yitirmektedir.

Wolf (2001: 117-134)'un türleri ile Immortall oyunu incelendiğinde oyunun "yakalama", "atlatma", "kaçış", "engelli parkur", "platform" şeklinde tanımlanması mümkündür. Çünkü oyunda yönetilen karakter, diğer karakterleri korumak için kurşun, bomba ve füzeleri "yakalamak" zorundadır. Ama oyuncu onlardan kaçmayı da tercih edebilir. Dolayısıyla "atlatma" mekaniği de yer almaktadır. Takip eden askerler, tanklar ve savaş uçaklarından "kaçılmaktadır". Bu engeller ilerleyerek aşıldığından oyuna "engelli parkur" olarak da bakılabilir. Son olarak oyunda farklı platformlar olmasa da oyunun oyun mekânını kullanma biçimi "platform" türünü de andırmaktadır. Bütün bunlar oyunun kaç oyuncu ile oynandığına, oyunda zamanın ve mekânın kurgulanışına, oyundaki engellerin ne şekilde işlediğine dair net olarak ayırt edici nitelikler sunmamaktadır. "Sanat oyunları", "gündelik oyunlar" veya diğer benzer oyun türlerinden daha açıklayıcı olsa da Wolf (2001)'un yaklaşımı da yetersiz ve kısmen de tutarsız görünmektedir. 
Tablo 3. Wolf (2001: 113-134) Kategorilerine Göre Örnek Oyunların Özellikleri

\begin{tabular}{|l|c|c|c|c|}
\hline & ImmorTall & Loved & $\begin{array}{c}\text { The Company of My- } \\
\text { self }\end{array}$ & Time Kufc \\
\hline Yakalama & $*$ & & & \\
\hline Atlatma & $*$ & $*$ & & $*$ \\
\hline Kaçış & $*$ & $*$ & & $*$ \\
\hline Engelli Parkur & $*$ & $*$ & $*$ & $*$ \\
\hline Platform & $*$ & $*$ & & $*$ \\
\hline Bulmaca & & $*$ & & $*$ \\
\hline Quiz & & & & $*$ \\
\hline Toplama & & & & $*$ \\
\hline Labirent & & $*$ & & $*$ \\
\hline
\end{tabular}

Kaynak: Wolf M J P (2001) Genre and the Video Game. The Medium of the Videogame, Mark J P W (Ed.), University of Texas Press, 113-134

Wolf'un tür kategorileri oyun formu ve içeriğinin birbiri içinde gelişigüzel eridiği muğlâk bir yaklaşım ve sonuçlar itibariyle de birbiriyle çakışan kategoriler sunmaktadır. Üstelik oyun mekaniklerinin incelenmesi de yüzeysel kalmaktadır.

Konu oyun mekaniklerinin belirlenmesi olduğunda Jarvinen (2009: 385-394)'in "uygulamalı ludoloji" yaklaşımı çok daha net ayrımlar ve daha geniş bir liste sunmaktadir.

Tablo 4. Jarvinen (2009: 385-394)'in Oyun Mekanikleri Listesi

\begin{tabular}{|c|c|c|c|c|}
\hline $\begin{array}{c}\text { Sürat artırma / } \\
\text { Sürat düşürme }\end{array}$ & $\begin{array}{c}\text { Hedefleme ve } \\
\text { vurma }\end{array}$ & Dağıtma & Dizme & $\begin{array}{c}\text { Saldırma / } \\
\text { Savunma }\end{array}$ \\
\hline $\begin{array}{c}\text { Teklif koyma, } \\
\text { bahis oynama }\end{array}$ & Tarama & İņ̧a etme & Alma / Satma & Yakalama \\
\hline Seçme & $\begin{array}{c}\text { Ses veya } \\
\text { görüntü dü- } \\
\text { zenleme }\end{array}$ & Ele geçirme & Anlaşma & Kontrol etme \\
\hline Konuşma & Elden çıkarma & Alan kapatma & İfade etme & $\begin{array}{c}\text { Gütme (yönlen- } \\
\text { dirme) }\end{array}$ \\
\hline Bilgi arama & Zıplama & $\begin{array}{c}\text { Manevra yap- } \\
\text { ma }\end{array}$ & Hareket & Oynatma \\
\hline $\begin{array}{c}\text { Harekete } \\
\text { geçirme }\end{array}$ & Performans & Yerleştirme & $\begin{array}{c}\text { Noktadan nok- } \\
\text { taya hareket }\end{array}$ & Güç gösterme \\
\hline Siralama & $\begin{array}{c}\text { Hızlanma / } \\
\text { Yavaşlama }\end{array}$ & Öykü anlatma & Veri girme & Yedek koyma \\
\hline Alma & $\begin{array}{c}\text { Takas - } \\
\text { değiştirme }\end{array}$ & Dönüştürme & $\begin{array}{c}\text { Geliştirme / } \\
\text { Geriletme }\end{array}$ & Oylama \\
\hline
\end{tabular}

Kaynak: Jarvinen A (2009) Games Without Frontiers: Methods for Game Studies and Design, VDM Verlag, http://ocw.metu.edu.tr/pluginfile.php/ 4468/mod_ resource/content/0/ceit706/week3_new/AkiJarvinen_Dissertation.pdf, Erişim tarihi: 13.11.2014 
Jarvinen'in (2009: 385-394) modeli gibi, oyun prosedürlerinin, oyun mekaniklerinin, oyun öğelerinin ve bu öğelerin sistem mi yoksa oyuncu mu tarafından kontrol edildiğinin incelendiği detaylı bir analiz bize oyunun formu ve oynanışı aç1sindan daha fazla şey söyleyecektir. Ancak konu tür olarak oyunun nereye oturduğunun belirlenmesi olduğundan oyun mekaniklerinin detaylı bir incelemesinden ziyade, oyunun oynanışına dair içerikten ziyade oyun biçimine dair unsurların merkezde olduğu ama yine de mekanikleri aşan bazı nitelikler için de net ayrımlar koyabileceğimiz bir yaklaşıma ihtiyaç duymaktayız. Burada Wolf (2001)'un birbiriyle çakışan kategorileri ne türün belirtilmesi, ne de oyun mekaniklerinin tariflenmesi için yeterli olmaktadır. Jarvinen (2009: 385-394)'in yaklaşımı ise bir oyunun oyun mekanikleri incelenirken işlevsel olabilir fakat türsel ayrımlar açısından kullanışlı değildir.

\section{5. ÇOK BOYUTLU BİR TIPOLOJIKK YAKLAŞIM MODELİ}

Aarseth-Smetstad-Sunnana modeli (2003: 48-53), bu modelin Elverdam-Aarseth tarafından revize edilmiş hali (2007: 3-22) ve Dahlskog-Kamstrup-Aarseth revizyonu (2009: 1-5), tür yaklaşımlarının keyfi, çelişkili ve üst üste binen kategorilerinin yerine daha net ve bilimsel bir yaklaşım sunmak iddiasını taşımaktadır. Bu açık uçlu ve çok boyutlu tipolojik yaklaşım, tüketiciye yönelik belirlenen veya tüketicinin belirlediği üst üste binmiş türlerin yerine başka analitik kategoriler sunmaktadir.

Modelde, 8 ana kategori bulunmaktadır: Sanal mekân, fiziksel mekân, diş zaman, iç zaman, oyuncu bileşimi, oyuncu ilişkisi, mücadele ve oyun durumu. Bu altı kategori altında 17 alt kategori bulunmaktadır ve oyunlar bu 17 kategori içinde kendi özelliklerinin nereye denk düştügü ile sinıflandırılmaktadır.

Aarseth-Smetstad-Sunnana (2003: 48-53) modelinde ele alınan oyunlar arasında platform oyunu örneği kullanılmamaktadır. Verilen en yakın örnek olan Lemmings (1991) de platform oyunlarının tipik bir örneği sayılamaz (Aarseth ve ark. 2003: 50). Dolayısıyla modelin platform oyunlarına uygulanması için bu yaklaşımin temel prensipleri doğrultusunda ilerlemek gerekmektedir. Modelin bütün oyunları kapsama iddiası bulunduğundan platform oyunlarının seçilmesi modelin geçerliliğini test etmek ve zayıf yönlerini sergilemek için avantaj sağlamaktadir. 
Selçuk İletişim, 2015, 9 (1): 363-387

Tablo 5. Aarseth-Smetstad-Sunnana (2003: 48-53) Modelinde Ana ve Alt Boyutlar

\begin{tabular}{|c|c|c|}
\hline \multirow{7}{*}{ Sanal mekân } & \multirow{2}{*}{ Perspektif } & Bütüncül \\
\hline & & Pozisyona göre \\
\hline & \multirow{2}{*}{ Konumlandırma } & Mutlak \\
\hline & & Göreli \\
\hline & \multirow{3}{*}{ Çevre dinamikleri } & Yok \\
\hline & & Sabit \\
\hline & & \begin{tabular}{|l|} 
Serbest \\
\end{tabular} \\
\hline \multirow{5}{*}{ Fiziksel mekân } & \multirow{2}{*}{ Perspektif } & Bütüncül \\
\hline & & Pozisyona göre \\
\hline & \multirow{3}{*}{ Konumlandırma } & Konum temelli \\
\hline & & Uzaklık temelli \\
\hline & & \begin{tabular}{|l} 
Her ikisi de \\
\end{tabular} \\
\hline \multirow{4}{*}{ Diş Zaman } & \multirow{2}{*}{ Temsil } & Benzer \\
\hline & & Keyfi \\
\hline & \multirow{2}{*}{ Teleoloji } & Sonlu \\
\hline & & Sonsuz \\
\hline \multirow{6}{*}{ İç Zaman } & \multirow{2}{*}{ Aciliyet } & Var \\
\hline & & Yok \\
\hline & \multirow{2}{*}{ Eş zamanlılık } & Var \\
\hline & & Yok \\
\hline & \multirow{2}{*}{ Tur kontrolü } & Var \\
\hline & & Yok \\
\hline \multirow{7}{*}{ Oyuncu bileşimi } & \multirow{7}{*}{ Bileşim } & Tek oyuncu \\
\hline & & Tek takım \\
\hline & & İki oyuncu \\
\hline & & İki takım \\
\hline & & Çoklu oyuncu \\
\hline & & Çok oyunculu \\
\hline & & Çok takımlı \\
\hline \multirow{5}{*}{ Oyuncu İlişkisi } & \multirow{2}{*}{ Oyuncu bağı } & Değişken \\
\hline & & \begin{tabular}{|l|} 
Sabit \\
\end{tabular} \\
\hline & \multirow{3}{*}{ Değerlendirme } & Bireysel \\
\hline & & Takım \\
\hline & & Her ikisi de \\
\hline \multirow{5}{*}{ Mücadele } & \multirow{3}{*}{ Engeller } & Aynı \\
\hline & & Duruma göre değişken \\
\hline & & Rakibe göre değişken \\
\hline & \multirow{2}{*}{ Hedef } & Mutlak \\
\hline & & Göreli \\
\hline \multirow{6}{*}{ Oyun durumu } & \multirow{3}{*}{ Değişkenlik } & Geçici \\
\hline & & Kalıcı \\
\hline & & Sinırsız \\
\hline & \multirow{3}{*}{ Kaydedilebilirlik } & Sinırsiz \\
\hline & & \begin{tabular}{|l|l} 
Sinırlı \\
\end{tabular} \\
\hline & & Yok \\
\hline
\end{tabular}


Dijital Oyunlara "Oyun Türü” Yaklaşımlarının Sorunları...

Kaynaklar: Aarseth E, Smedstad S M ve Sunnana L (2003) A Multidimensional Typology of Games. Digra 2003 Conference Proceedings, Utrecht University, 4853; Elverdam C ve Aarseth E (2007) Game Classification \& Game Design: Construction Through Critical Analysis, Games and Culture, Cilt 2, Sayı 1, 3-22

Modelin uygulanmasında oyunun bilgisayar oyunu olup olmamasına bağlı olarak "sanal mekân" veya "fiziksel mekân" kategorilerinden yalnızca biri seçilmektedir. Fakat "alternatif gerçeklik oyunları", yani oyunun hem "sanal" hem "fiziksel" düzlemde geçtiği oyunlarda iki kategori de kullanılabilir. Bizim ele aldığımız oyunların hepsi bilgisayar oyunları olduğu için burada sadece "sanal mekân" kategorisi devreye sokulacaktır. Modeldeki "oyuncu ilişkisi" de çok oyunculu oyunlar için anlam taşımaktadır. Bu çalışmada örnek alınan oyunların hepsinde oyuncu bileşimi tek oyunculu olduğundan oyuncular arasında bir ilişkiden bahsedilemez ve dolayısıyla oyuncu bileşimi kategorisini de bir kenara bırakabiliriz.

\section{MODELIN UYGULANMASI VE BULGULAR}

Aarseth-Smetstad-Sunnana modeli (2003: 48-53) ele alınan platform oyunlarına uygulandığında oyunların birbirinden farklılıkları daha net olarak ortaya çıkmaktadır. Öte yandan bu uygulama modelin yeterliliği konusunda da fikir vermektedir.

Sonuçlar incelendiğinde bütün oyunlarda oyuncuların oyun dünyasına "göreli" olarak konumlandırıldığı, yani oyuncunun yönettiği karakterin satranç oyununda olduğu gibi mutlak bir koordinatı olmadığı görülmektedir(17). Oyunların hepsi sonlu bir "teleolojiye" sahiptir, yani tekrarlı veya bitmeyen bir oyun yapisı bulunmamaktadır(18). Bunlar platform türünün tipik özellikleri olarak düşünülebilir. Ayrıca oyunların hepsi tek oyunculudur(19).

Immortall ve Loved oyunu tek seviyeden (level) oluşmaktadır ve oyuncu oyun dünyasının karakterin yer aldığı bölümünü görebilmektedir. The Company of $M y$ self ve Time Kufc oyunları farklı seviyelerden oluşmakta ve oyuncu ancak bir seviyeyi bütünüyle (omnipresent) görebilmektedir. Immortall hariç bütün oyunlarda oyunu kaydetme imkânı bulunmaktadır. Kaydetme işlemi Loved'da bir oyun öğesine dokunarak, diğer iki oyunda ise seviye atladıkça gerçekleştiğinden kaydedilebilirlik sinırlıdır (20). 
Tablo 6. Aarseth-Smetstad-Sunnana (2003: 48-53) Modeline Göre İncelenen Oyunların Özellikleri

\begin{tabular}{|c|c|c|c|c|}
\hline Boyutlar & Immortall & Loved & $\begin{array}{c}\text { The Company } \\
\text { of Myself }\end{array}$ & Time Kufc \\
\hline Perspektif & $\begin{array}{c}\text { Pozisyona } \\
\text { göre }\end{array}$ & $\begin{array}{c}\text { Pozisyona } \\
\text { göre }\end{array}$ & Bütüncül & Bütüncül \\
\hline Konumlandirma & Göreli & Göreli & Göreli & Göreli \\
\hline Çevre dinamikleri* & Yok $^{*}$ & Yok $^{*}$ & Serbest & Sabit* \\
\hline Zamanın temsili** & Keyfi** & Keyfi** & Keyfi** & Keyfi** \\
\hline Teleoloji & Sonlu & Sonlu & Sonlu & Sonlu \\
\hline Aciliyet* & Var* & Var* & Var* & Var* \\
\hline Eş zamanlılık & Var & Var & Kismen yok ${ }^{*}$ & Var \\
\hline Tur kontrolü & Yok & Yok & Kismen var* & Yok \\
\hline Oyuncu bileşimi & Tek oyuncu & Tek oyuncu & Tek oyuncu & Tek oyuncu \\
\hline Engeller* & Ayni* & $\begin{array}{l}\text { Duruma göre } \\
\text { değişken* }\end{array}$ & $\begin{array}{l}\text { Duruma göre } \\
\text { değişken* }\end{array}$ & $\begin{array}{l}\text { Duruma } \\
\text { göre } \\
\text { değişken* }\end{array}$ \\
\hline Hedefler & Göreli & Göreli & Mutlak & Mutlak \\
\hline $\begin{array}{l}\text { Oyun durumundaki } \\
\text { değişiklikler* }\end{array}$ & Yok $^{*}$ & Yok $^{*}$ & Yok $^{*}$ & Yok $^{*}$ \\
\hline Kaydedilebilirlik & Yok & Sinirli & Sinırli & Sinırlı \\
\hline
\end{tabular}

* İncelenen oyunlar bu kategoride araştırmacının yorumuna bağlı olarak birden fazla duruma yerleştirilebiliyor

** Modelde zamanın temsilinin oyunlarda belirlenmesinde sorunlar ortaya çıkmaktadır.

Aarseth-Smetstad-Sunnana modeli bağlamında bu kategoriler dişında kalan boyutların analizini yaparken ayn kolaylığı sağlamamız üç nedenle mümkün değildir. Birincisi, modelin platform oyunları için revize edilmesi ihtiyacı ortaya çıkmaktadır. İkinci olarak, ele aldığımız oyunlar platform türü içinde de bazı yenilikçi oynama biçimleri sunmaktadır. Son olarak modelin özellikle oyun zamanı konusunda bazı problemleri olduğu ortaya çıkmaktadır.

\subsection{Modelin "Oyunun Hedefleri" İle İlişkili Sorunları}

Oyunları modelde yer alan "hedefler" başlığı açısından incelediğimizde oyuncunun oyunu kazanma ve kaybetme durumlarını ele almamız gerekmektedir. "Kazanma durumları" farklı seviyelere veya oyuncunun yaklaşımına göre değişiyorsa göreli hedeflerden bahsediyoruz demektir. Ele aldığımız oyunlardaki kurallar bağlamındaki kazanma durumlarını ele alırsak, herhangi bir puanlama mekanizması olmadığından oyun dünyasının sonuna varmak ana hedef olarak ortaya çıkmaktadır. 
Dijital Oyunlara “Oyun Türü” Yaklaşımlarının Sorunları...

Öte yandan oyunlar entegre edildikleri oyun sitelerinde bazı kazanım derecelendirmeleri (achievement) içerecek şekilde yer almaktalar(21). Bu kazanımlar ölçülebilir ve mutlaktır. Oyuncular bu hedeflere göre de oynayabilme imkânına sahiptir.

Ayrıca ImmorTall oyununda oyuncuyla birlikte hareket eden aileyi korumak veya korumamak gibi seçimler yapılabildiğinden oyunda farklı sonlara varma imkânı bulunmaktadır. Benzer şekilde Loved oyununda oyuncunun "itaatkâr" veya "isyankâr" bir oyun tarzı sergilemesine göre oyun iki farklı sonla bitebilmektedir.

Eğer oyunlardaki hedefler oyuncunun öznel hedeflerin de gözetilerek ele alınırsa bütün oyunların göreli kazanma durumları olduğu sonucuna varılacaktır. Bu durum modelin hedefler konusuna yaklaşımı ile ilgili bir problemi göstermektedir. Eğer modelin prensipleri kabul edilirse, oyuncunun öznel hedeflerinin oyunun kendisine "dişsal" olarak yer aldığı sonucuna varılacaktır. Bu çerçevede ImmorTall ve Loved oyunlarının göreli diğerlerinin ise mutlak kazanma durumları olduğu söylenebilir.

Tablo 7. Aarseth-Smetstad-Sunnana (2003: 48-53) Modeli, Kazanım (Achievement) Sistemleri Ve Oyuncuya Göre Hedeflerin Karşılaştırılması

\begin{tabular}{|l|c|c|c|c|}
\hline & Immortall & Loved & $\begin{array}{c}\text { The Company } \\
\text { of Myself }\end{array}$ & Time Kufc \\
\hline $\begin{array}{l}\text { Modele göre } \\
\text { hedefler }\end{array}$ & Göreli & Göreli & Mutlak & Mutlak \\
\hline $\begin{array}{l}\text { Kazanım sistemle- } \\
\text { rine göre hedefler }\end{array}$ & Mutlak & Mutlak & Mutlak & Mutlak \\
\hline $\begin{array}{l}\text { Oyuncunun kendi } \\
\text { hedeflerine göre }\end{array}$ & Göreli & Göreli & Göreli & Göreli \\
\hline
\end{tabular}

\subsection{Modelin "Oyun Durumu" İle İlişkili Sorunları}

"Oyun durumundaki değişiklikler" kategorisi oyun durumunun oyuncuyu nasıl etkilediğiyle ilişkilidir. Model burada oyuncuyu güçlendiren oyun nesneleri (power-ups), World of Warcraft(2004) gibi oyunlardaki oyuncu seviyeleri ve strateji oyunlarındaki ünite geliştirmeleri düşünülerek düzenlenmiştir (Aarseth ve ark. 2003: 52). Ele aldığımız hiçbir oyunda karakteri güçlendirecek bir öğe bulunmamaktadır. Öte yandan güçten düşürecek öğelere rastlamaktayız. Modelin (Aarseth ve ark. 2003: 53) bu kategoride sunduğu en yakın oyun örneği Pacman(1980)'dir. Pac-man'de, karakterimiz topladığında düşmanların oyuncunun karakterini takip etmek yerine bizden kaçtığı "haplar" bulunmaktadır. Bu ve benzeri öğeler "FPS", "gerçek zamanlı strateji" veya "kitlesel çevrimiçi oyunlar" türleri altında ele alınabilecek oyunlarda kolayca tespit edilebilir ama tek oyunculu "platform" türü altında değerlendirilebilecek oyunlarda benzer öğelere daha az rastlanmaktadır. Bu da oyunlarda oyun durumunun değişsiminin oyuncuya 
etkisiyle ilgili daha başka ve daha detaylı bazı kıstasların modele eklenmesi gerektiğini gösteriyor.

\subsection{Modelin "Engeller" İle İlişkili Sorunları}

Oyunlardaki mücadeleyi belirleyen engellerin yer alışı da detaylı bir incelemeyi hak etmektedir. Bu çalışmadaki örnek oyunlar tek oyunculu olduğundan ve bilgisayarın yönettiği, yapay zekaya sahip, oyuncu rolü yapan rakipler de olmad1ğından rakiplerin durumu bir kenara bırakılabilir. Fakat model doğrultusunda bu oyunlarda engellerin sabit mi yoksa duruma göre değişken mi olduğu konusunda seçim yapmak sıkıntılar içermektedir.

Immortall'da oyuncunun karşısına çıkan düşmanlar benzer olsa da farklı açılarla farklı zamanlarda farklı noktalara ateş edebilmekteler. Bu da engellerin belli bir sistematiğe bağlı olarak değişken olduğunu düşündürmektedir. Öte yandan modelde bu tür oyunlar sabit engelli olarak yer almaktadır.

Loved oyununda hareketli tuzaklar (yıldız biçimli güdümlü nesneler) oyunu her oynadığınızda hep aynı yerden harekete başlayıp oyuncunun konumuna göre hareket ederek saldırmaktadır. Ama oyuncunun seçimine göre oyun dünyasının temsili daha zor görülür-algılanır ve daha kaotik bir biçime girdiğinden belki de engellerin değişken olduğu ifade edilmelidir. Ancak yine modele göre sabit olmaları gerekmektedir.

The Company of Myself te engeller sabittir, ancak oyuncu zaman içinde geriye gidip kendini kopyalayabilmektedir ve kendi bedenini platform olarak kullanarak bir yerden bir yere sıçrayabilmektedir. Bu değişken "beden platformlar" oyun açısından bir engel de oluşturabilir, oyuncunun işini de kolaylaştırabilir. Bu durum oyunda engellerin değişken olabileceğini de düşündürmektedir.

Time Kufc oyuncunun kendi oyun seviyesini yaratmasına imkân tanımaktadır, bu da farklı seviyelerde benzer olmayan engelleri imkânlı kılmaktadır. Oyunun senaryo ve seviye temelli normal oyun modunda da farklı seviyeler birbirinden farklı engeller içermektedir.

Sonuçta örnek dört oyun birlikte düşünüldügünde platform oyunlarında engellerin tasarım olarak sabit görünmesine rağmen oyunun oynanması sırasında değişken bir yapının ortaya çıktığı söylenebilir. Üstelik örnek olarak alınan platform oyunları zaman ve mekânla ilgili yaratıcı bazı deneylere giriştiğinden özelliklerini belirlemek daha da zorlaşmaktadır. Model bu kategoride Neverwinter Nights (2002) gibi bir RPG oyununu ve Call of Duty (2003) gibi bir FPS oyununu bile önceden tanımlı sabit engeller içerecek şekilde içermektedir. Değişken engeller ise Tetris (1984), Solitaire, Rulet, Simcity (1989) ve Diablo (1996) gibi oyunları içermektedir. Neverwinter Nights oyununun tek oyunculu senaryo modunda çok 
Dijital Oyunlara "Oyun Türü" Yaklaşımlarının Sorunları...

sayıda büyü ve silahı kullanarak yapay zeka ile yönlendirilen NPC'lere karşı oyun uzaminda önceden tahmin edilemez taktiklerle oynamak mümkündür. Neverwinter Nights (2002) oyununun, Diablo (1996) veya Simcity (1989) kadar değişken engeller yaratamadığının ileri sürülmesi modelin geçerliliğini zayıflatan bir başka unsur olarak dikkat çekmektedir.

Aarseth-Smetstad-Sunnana modelinin oyun mekânı ve zamanı ile ilgili boyutları daha fazla problem ortaya çıkarmaktadır. Daha önce de belirttiğimiz gibi platform oyunlarının model açısından örneklendirilmemiş olmasının yanında, bu çalışmada ele alınan platform oyunlarının deneysel ve yenilikçi özellikler içeriyor olması modelin uygulanmasını zorlaştırmaktadır.

Tablo 8. Aarseth-Smetstad-Sunnana (2003: 48-53) Modeli, Oyunların Sunduğu İmkanlar, Görsel Değişimler ve Oynanışa Göre Engeller

\begin{tabular}{|l|c|c|c|c|}
\hline & Immortall & Loved & $\begin{array}{c}\text { The Com- } \\
\text { pany of My- } \\
\text { self }\end{array}$ & Time Kufc \\
\hline $\begin{array}{l}\text { Modele göre } \\
\text { engeller }\end{array}$ & Aynı & Aynı & Aynı & Aynı \\
\hline $\begin{array}{l}\text { Seviye tasarımı } \\
\text { imkanı ile engeller }\end{array}$ & Aynı & Aynı & Aynı & $\begin{array}{c}\text { Duruma göre } \\
\text { değişken }\end{array}$ \\
\hline $\begin{array}{l}\text { Oyun dünyasındaki } \\
\text { görsel değişimlere } \\
\text { göre dolaylı engeller }\end{array}$ & Aynı & $\begin{array}{c}\text { Duruma Göre } \\
\text { Değişken }\end{array}$ & Aynı & Aynı \\
\hline $\begin{array}{l}\text { Oynanışa göre } \\
\text { engeller }\end{array}$ & $\begin{array}{c}\text { Duruma göre } \\
\text { değişken }\end{array}$ & $\begin{array}{c}\text { Duruma göre } \\
\text { değişken }\end{array}$ & $\begin{array}{c}\text { Duruma göre } \\
\text { değişken }\end{array}$ & Aynı \\
\hline
\end{tabular}

\subsection{Modelin "Çevre Dinamikleri" İle İlişkili Sorunları}

Oyun dünyasıyla ilişkili olan "çevre dinamikleri" modelde oyuncunun oyun dünyasına oynanış(gameplay) sırasında katkısının boyutunu belirlemek için işlev görmektedir. Oyuncu oyuna ya hiçbir ekleme yapmadan oynamaktadır, ya önceden tanımlı bazı değerleri değiştirmektedir ya da oyunda daha serbest bir biçimde ekleme ve düzenlemeler yapmanın imkanı bulunmaktadır.

ImmorTall'da oyuncunun oyun içindeki eylemiyle oyun dünyasında görsel bazı değişimler meydana gelmektedir. Bu değişimler sadece oyun atmosferini etkilediğinden oyun biçimine yönelmiş bir analizde dikkate alınmayabilir.

Ancak benzer değişimler Loved oyununun oyun dünyasının kaotik bir yapıya bürünmesine neden olduğundan ve örneğin tuzaklar artık tuzak gibi görünmediğinden bu durum kolaylıkla analiz dışında bırakılamaz. Modelin platform oyununa en yakın örneği olan Lemmings oyunu modelde serbest çevre dinamiklerine örnek olarak verilmektedir. Loved, Lemmings oyunundaki gibi oyuncunun kontrolünde mekâna serbestçe eklenen oyun öğeleri içermemektedir, ancak yine 
de oyuncunun "itaatkâr" veya "isyankâr" oyun tarzına göre oyun sistemi oyun mekânına gelişigüzel müdahalelerde ve eklemelerde bulunmaktadır. Bu durumun oyunun türüne etkisi, ya engellerin değişken olduğu belirtilerek ya da burada ele alınan çevre dinamiklerinin oyunda belirli bir derecede de olsa değişime imkan tanıdığı söylenilerek modelin uygulamasına dahil edilebilir. Ancak model bu durumun görmezden gelinmesini veya öğelerin oyunu değiştiren bir unsur değil sadece efekt olarak Varolcuğunun dikkate alınmasını, böylece oyunun ImmorTall gibi çevre dinamiklerinin olmadığı bir oyun olarak kategorize edilmesini teşvik etmektedir.

The Company of Myself oyununda oyuncu kontrolündeki karakterin klonları (geçmiş zamandaki kopyaları) oyun dünyasına sadece görsel olarak değil oyuna etkileri ile birlikte de katılmaktalar. Hatta bulmacaların onlar olmadan çözülmesi imkânsızdır. Bu durum Lemmings(1991) oyununda bazı Lemming'lerin diğerlerini çıkışa ulaştırmak için kullanılmasına benzetilebilir. Bu oyunun serbest çevre dinamiklerine sahip olduğu diğer örneklere göre daha açıtır.

Time Kufc, oyun dünyasının farklı boyutlardaki yansımalarının gösterilmesi, yerçekiminin değiştirilmesi ve oyun haritasının saat yönünde çevrilmesi gibi imkanlar sunmaktadır. Bunlar sabit çevre dinamikleri olarak ele alınabilir. Ama böyle sinıflandırıldığında oyunun bütün bu özelliklerle birlikte ortaya çıkan karmaşık yapısının diğer platform oyunlarıyla farkını ortaya koyma imkanı da ortadan kalkar. Örneğin burada bahsi geçen diğer kategorileri de düşünerek The Company of Myself serbest çevre dinamikleriyle Time Kufc'tan daha kompleks bir oyun olmalıdır. Ama gerçekte Time Kufc tasarlanmış en karmaşık ve zor "bulmacalı platform" (puzzle platformer) türü oyunlardan biridir. Model burada satranç oyunu gibi oldukça kompleks bir oyunu da çevre dinamikleri içermeyen bir oyun olarak ele aldığından burada yöneltilebilecek eleştirilerin önünü bir ölçüde kapatmaktadır. Yine de ImmorTall ve Loved oyunlarındaki mekansal değişimlerin sadece görsel mi olduğu, yoksa oyunsal yansımalarının da mı hesaba katılması gerektiği tartışması modelin geçerliliği açısından önemini korumaya devam etmektedir.

Tablo 9. Aarseth-Smetstad-Sunnana (2003: 48-53) Modeli, Oynanışa Etki Eden ve Etmeyen Öğelere Göre Çevre Dinamikleri

\begin{tabular}{|l|c|c|c|c|}
\hline & Immortall & Loved & $\begin{array}{c}\text { The Company } \\
\text { of Myself }\end{array}$ & Time Kufc \\
\hline $\begin{array}{l}\text { Modele göre çevre } \\
\text { dinamikleri }\end{array}$ & Yok & Yok & Serbest & Sabit \\
\hline $\begin{array}{l}\text { Oynanışa etkisi } \\
\text { olmayan çevre } \\
\text { dinamikleri }\end{array}$ & Sabit & Serbest & Serbest & Sabit \\
\hline $\begin{array}{l}\text { Oynanışa etkisi } \\
\text { olan çevre dina- } \\
\text { mikleri }\end{array}$ & Yok & Serbest & Serbest & Sabit \\
\hline
\end{tabular}


Dijital Oyunlara “Oyun Türü” Yaklaşımlarının Sorunları...

\subsection{Modelin "Oyun Zamanı" İle İlişkili Sorunları}

Son olarak modelin en zayıf noktası olan zaman ile ilgili olan yaklaşım üzerinde durmak gerekmektedir. "Dış zaman" ana kategorisinin "zamanın temsili" alt kategorisi zamanın oyunda gerçek zamanla benzer veya farklı işlemesi durumlarını belirlemede kullanılmaktadır. Burada model (Elverdam ve Aarseth 2007: 1011) örnek olarak Starcraft (1998) oyununda birkaç dakikada inşa edilen binaların gerçek hayatta inşasının yıllarca sürmesini ele alıp, Starcraft'ta zaman temsilinin keyfi olduğunu söylemektedir.

Modelin oyun tipolojisine dair oyunsal özellikleri inceleyerek sunduğu bütün diğer kategoriler oyun mekanikleri veya oyunsal öğeler çerçevesine otururken "zamanın temsili" bu biçimsel analiz yörüngesinden saparak modeli riske atmaktadır. Herhangi bir oyunda herhangi bir eylemin gerçek hayatta ne kadar sürdüğüyle ele alınması oyunun anlatısı açısından elbette bir anlam içermektedir ancak oyun yapısına veya oyun biçimine yönelen bir çalışmada sorun yaratmaktadır. Gerçek hayatta bir şeyin ne kadar sürdüğü ve oyunda ne kadar sürdügünü belirlemek anlatı ile ilişkili sorular ortaya çıkaracaktır. Bu sorular da sadece biçimci bir yaklaşım ile çözülemez.

The Company of Myself oyununun ana karakteri olan çekirge gerçekte olduğu hızla mı yoksa ağır çekimde mi sıçramaktadır? Loved oyununun dünyasında zaman nasıl işlemektedir veya gerçekte nasıl işlemesi gerektiğinin karşılığ bulunabilir mi? Time Kufc ve The Company of Myself teki zamanda geriye veya ileriye gitme durumu bu kategoride nasıl ifade bulabilir? ImmorTall'da karakterimiz ilerlerken günler mi yoksa aylar mı geçmektedir? Bu soruların Aarseth'in modelinde herhangi bir cevabı bulunmamaktadır. Dolayısıyla modele ait zamanın temsili boyutu tamamen modelin yöntemiyle ve yaklaşımıyla uyumsuzdur. Bunlara verilecek öznel yanıtlar ancak anlatısal bir analiz içinde değer kazanabilir. Oyun sistemini oyunsal özellikleri (biçimle ilişkili özellikler) ile inceleyen bir analiz bu sorulara net cevaplar veremeyecektir.

Aarseth-Smetstad-Sunnana modelinde zamanla ilgili daha az sorunlu ama yine de dikkatle ele alınması gereken bir dizi kategori daha bulunmaktadır. "Aciliyet" kategorisi her ne kadar platform oyunları için revize edilmeye ihtiyaç duysa da, ele alınan oyunlarda oyun durumunun gerçek zamana bağlı olarak benzer miktarda değiştiği veya değişmediği ileri sürülerek bu kategorinin örnek platform oyunlarında büyük bir sorun içermediği söylenilebilir. Platform oyunları, düşük hızda oynanan "karar alma anları" kadar daha acil hareket etmeyi gerektiren "eylem anları" da içermektedir. Bu yüzden aciliyetin ne var olduğunu ne de yok olduğu belirlenebilir. Bu durumda en mantıklı çıkış yolu kategorinin daha fazla sayıda seçenek içerecek şekilde geliştirilmesidir. 
"Eş zamanlılık" ve "tur kontrolü" sırayla oynanan (turn based) oyunlar için önem taşımaktadır. Bu iki kategorinin farklı kombinasyonları basitçe tur bazlı (turn based) diyemeyeceğimiz kadar farklı örnekleri içermektedir. Modelde "tur bazlı" oyunların eş zamanlı oynanan ve oynanmayan örnekleri bulunmaktadır. Ele alınan platform oyunlarının ilk bakışta tur bazlı olmadıkları düşünülebilir. Ancak The Company of Myself bir yenilik sunarak tur sisteminin olmayacağı yönündeki beklentileri boşa çıkarmaktadır. Bu oyunun ilerleyen seviyelerinde oyuncu yönettiği karakterin klonlarını üreterek (veya zamanda geriye giderek karakterin geçmişteki hallerini) oynama imkânına sahiptir. Bu oynama biçimi tur kontrolü (turn based) içermektedir ve eş zamanlıdır. Eş zamanlı olmasının nedeni karakteri oynatıp turu geçtikten sonra, karakterin klonunu oynatılırken eski klonun daha önce yapılmış olan hareketleri bilgisayar kontrolünde tekrarlıyor olmasıdır. Böylece onlarca kopya üretildiğinde bu kopyalar kendi başlarına eş zamanlı, bazen düzenli bazen de kaotik olarak hareket etmeye başlarlar.

Aynı oyununun başka bölümlerinde karakterin kız arkadaşı öyküye dahil olmakta ve oyuncu onu da yönetmeye başlamaktadır. Bu bölümlerde karakterler eş zamanlı olarak hareket etmemektedir. Dolayısıyla aynı oyunda tur kontrolünün de eş zamanlılığın da farklı kombinasyonları yer almaktadır. Bu durumu modele yansıtmak mümkün görünmemektedir. Aarseth bu durumda başat öğenin ele alınması gerektiğini söylemektedir, fakat başat öğenin hangisi olduğu tamamen araştırmacının yorumuna kalmıştır. Bu durum da model açısından sıkıntı doğuruyor.

Tablo 10. Aarseth-Smetstad-Sunnana (2003: 48-53) Modeli ve Oyunlardaki Kısmi Öğelere Göre Tur Kontrolü ve Eş Zamanlılığın Yer Alışı

\begin{tabular}{|l|c|c|c|c|}
\hline & Immortall & Loved & $\begin{array}{c}\text { The Company of } \\
\text { Myself }\end{array}$ & Time Kufc \\
\hline $\begin{array}{l}\text { Modele göre } \\
\text { tur kontrolü }\end{array}$ & Yok & Yok & Yok & Yok \\
\hline $\begin{array}{l}\text { Oyundaki karakterlere } \\
\text { göre tur kontrolü }\end{array}$ & Yok & Yok & $\begin{array}{c}\text { Bazı } \\
\text { seviyelerde var }\end{array}$ & Yok \\
\hline $\begin{array}{l}\text { Modele göre eş } \\
\text { zamanlılık }\end{array}$ & Var & Var & Var & Var \\
\hline $\begin{array}{l}\text { Oyundaki karakterlere } \\
\text { göre tur kontrolü }\end{array}$ & Var & Var & $\begin{array}{c}\text { Bazı } \\
\text { seviyelerde yok }\end{array}$ & Var \\
\hline
\end{tabular}

Son olarak, dört platform oyunu karşılaştırıldığında, oyunların modelin bu çalışmada üstünde durulan 13 kategorisinin 7'sinde birbirinden farklılıklar içerdiği ortaya çıkmaktadır. Aynı tür içinde yer alabilen, birbirine benzer 4 örnek oyunun bu derece farklılıklar içeriyor olmaları şaşırtıcı bir sonuçtur. Geriye kalan benzer özellikler içerdikleri 6 kategori de tür olarak bu oyunları canlandıracak bir tablo oluşturmamaktadır. Bu tablo aynı zamanda bilimsel çalışmalara girmiş olan po- 
Dijital Oyunlara “Oyun Türü” Yaklaşımlarının Sorunları...

püler tür kategorilerinin oynanış ve oyunsal nitelikler açısından tanımlayıcılığının ne kadar zayıf olduğunu yeniden gözler önüne sermektedir.

\section{SONUÇ}

İletişim bilimleri alanında yapılan oyunlara yönelik çalışmaların bir bölümü gerek yöntem, gerek örneklem olarak oynanış (gameplay) merkezli değil görsellik, tema, öykü gibi öğelere göre belirlenmektedir. Oyun türlerinin nasıl ele alınacağ temel olarak bu büyük problemin önemli bir parçasıdır. Araştırmacının oyunları oynayarak analiz etmesi ile oyun videoları izleyerek, oyunlar hakkında okuyarak fikir sahip olması sonuçlarda farklılıklar ortaya koymaktadır. Yapılan çalışmalarda oynanışa yönelik literatür taramaları ve örneklerin eksikliği kendini varolan popüler oyun türü sınıflandırmalarının bilimsel çalışmalara gelişigüzel sızması olarak göstermektedir.

$\mathrm{Bu}$ çalışmada üç önemli soruya yanıt aranmıştır. Birincisi daha nitelikli bir tür analizi için oyunların nasıl ve hangi özellikleriyle ele alınması gerektiğidir. Endüstri ve tüketici arasında bir uzlaşma olarak ortaya çıkan popüler oyun türü sınıflandırmalarının eksik ve yanlış yönleri belirlenmiştir. Benzer olarak Flash oyunları, gündelik oyunlar, sanat oyunları gibi sınıflandırmalar da bilimsel çalışmalar açısından verimli sonuçlar sunmamaktadır. Oyunsal özellikleri (prosedürel, etkileşimli, oynanışa göre belirlenmiş) ele alan daha net kategorilerin ihtiyacı göze çarpmaktadır. Oyunların tür yaklaşımı içinde ve genel anlamda sadece görsel öğeler ve tema üzerinden ele almanın eksik yönleri ortaya çıkmıştır. İletişim bilimleri içindeki oyuna yönelik araştırmalarda varolan oyunun oynanışını (oyun mekanikleri, oyun sistemi ve oyun dünyası ile birlikte) denklemin dışında tutan çalışmalar açısından bu tablo ciddi eksiklikleri gözler önüne sermektedir.

İkinci olarak, örnek alınan oyunların oyunun oynanışına (gameplay) dair tür analiziyle ne gibi özelliklerinin ve farklılıklarının ortaya çıtığı incelenmiştir. Yeni platform oyunlarının zaman ve mekânın düzenlenmesi ile ilgili yenilikçi bazı öğeler içerdiği ortaya konulmuştur.

Son olarak, örnek oyunların incelenmesi ile kullanılan Aarseth-SmetstadSunnana (2003) modelinin geçerliliği sınanmıştır. Aarseth-Smetstad-Sunnana (2003) modeli benzer çalışmalara göre daha net kategoriler sunsa da ciddi sorunlar içermektedir. Kısıtlı sayıda platform oyununun tür yaklaşımı içinde ele alınması araştırmacının oyunların yapısal özelliklerini daha derinlikli olarak düşünmesine olanak sağlayabilir, ancak türe yönelik böyle bir yaklaşımdan beklenti çok sayıda oyunun model bağlamında sıkıntı yaratmaksızın kolayca tasnif edilmesidir. Bu çalışmada ele alınan dört yeni platform oyununun modele oturtulması için modelin ciddi bir revizyondan geçmesi gerektiği ortaya çıkmıştır. Daha fazla sayıda ve birbirinden farklı özelliklere sahip oyunun modeldeki çok daha ciddi sorunları ortaya koyacağını düşünmek şaşırtıcı olmayacaktır. 
Gelecekte yapılacak çalışmalar açısından iki önemli noktanın altını çizme gereği ortaya çıkmıştır. Öncelikle uluslararası ölçekte derinleşmekte olan oyun araştırmaları literatürü ile iletişim bilimleri alanının bağının kurulması gerekmektedir. İkinci olarak, oyunlara ait öğelerin incelenmesinde, kuramsal çerçevede oynanışın (gameplay) merkeze oturtulması yöntem ve örneklem üzerinde, dolayısıyla da sonuçlar açısından daha sağlıklı bir yaklaşım olacaktır.

\section{SONNOTLAR}

(1) Fencott ve ark. (2012: 20) popüler oyun dergilerinde yer alan 80 farklı oyun türü belirlemişlerdir.

(2) "3 boyutlu oyunlar" oyun dünyasını ifade etmekle birlikte, dolaylı olarak oyunun üretim teknolojisini de belirtir. 3 boyutlu oyunlar modelleme, doku kaplama, canlandırma gibi görsellerin üretimine dair farklı yöntemlerle üretilmektedir. Ayrıca 3 boyutlu oyunların çoğu örneği fizik kanunlarının oyuna taşınması edeniyle simülasyon niteliği de taşımaktadır.

(3) "MMO" türü "MMOFPS" veya "MMORPG" gibi isimler alabilmektedir. "MMOFPS" kitlesel çevrimiçi birinci şahıs aksiyon oyunlarını, "MMORPG" ise kitlesel çevrimiçi rol yapma oyunlarını ifade etmektedir.

(4) Oynanış (gameplay) kavramı oyun araştırmaları literatüründe önemli bir yer tutmaktadır. Bir oyunun niteliklerini kavrayabilmek, oyunu tanımlayabilmek için başat kriter oynanış (gameplay) olarak ele alınmaktadır. (Zimmerman ve Salen 2004: 303-305; Juul 2005: 83-92; Aarseth 2003)

(5) Eğitim oyunları literatürde "serious games" veya "edugames" başlıkları altında incelenmektedir.

(6) Oyuncuların beklentisi açısından "rol yapma oyunları" veya "aksiyon macera" oyunları ifadeleri aynı zamanda oyunda kullanılan kamera açısı, oyunun iki boyutlu veya üç boyutlu olması gibi özelliklere dair bir izlenim de uyandırmaktadir.

(7) Android iştelim sistemini kullanan cihazlar için Google Play ve IOS işletim sistemini kullanan cihazlar için AppStore uygulamalarıyla indirilebilecek çok sayıda oyun bulunmaktadır.

(8) Dijital dağıtım kanalları arasında Steam, Desura, Origin gibi örnekler bulunmaktadır.

(9) Bağımsız Oyun Festivali 1998 yılından beri düzenlenmekte olup öğrenci yapımları ve bağımsız oyunların desteklenmesi konusunda önemli bir işlev görmektedir. Festivalin bir de yarışma bölümü bulunmaktadır.

(10) Kongregate, www.kongregate.com

(11) Newgrounds, www.newgrounds.com 
Dijital Oyunlara “Oyun Türü” Yaklaşımlarının Sorunları...

(12) Adobe Flash yazılımı, web tasarımı, animasyon ve oyun gibi alanlarda hem animasyon hem de programlama imkanını birlikte sunması, tarayıcı ekranında dinamik multimedia uygulamalarına imkan vermesi nedeniyle tercih edilmektedir.

(13) Oyun motoru (game engine), kurallar ve görsel öğelerin olmadığı haliyle bir oyun için gerekli program tabanını sağlayan asgari teknik altyapıyı sunan yazılımdır. Popüler oyun motoru örnekleri arasında Source, Unreal ve Unity oyun motorları bulunmaktadır.

(14) Akıllı cep telefonlarıyla gittikçe yaygınlaşan, kolayca indirilen oyunlar daha önce bilgisayar oyunu oynamamış çok sayıda insanı bu alana çekmektedir. "Gündelik oyunlar", sadece oyunlarla yetişmiş ve uzun saatlerini bilgisayar başında geçiren yeni nesile değil her yaşa ve her kesime hitap eden oyunlar olarak görülebilir.

(15) Oyun boyunca karakterin düşünceleri oyun dünyasının farklı seviyelerinde metin olarak ekrana yansitılmaktadır.

(16) Sanatsal ifadeler içerdiği iddia edilebilecek oyunları birbirine bağlayan temel bir oynanış (gameplay) bulunmamaktadır. Bu oyunları birbirine belirli belirsiz bağlayan nokta ancak bağımsız oyun stüdyolarının ürünü olan oyunlar olmaları itibariyle oyun endüstrisinin bazı kalıplarına karşı çıkarak bazı görsel denemeler ve oynanış açısından yenilikler sunmaları olabilir.

(17) Satranç oyununda taşların bulundukları mutlak konuma göre harf ve sayı ile koordinatları verilebilir. Bilgisayar oyunlarının bazı örnekleri bu konum mantığını taşımakla birlikte, oyun nesnelerinin mutlak koordinatlarının olmadığı, serbestçe hareket ettikleri örnekler de bulunmaktadır.

(18) Son dönemde çok sayıda oyun "açık uçlu" olarak ifade edilen, oyunun tasarımcı tarafından belirlenmiş bir bitiş anının bulunmadığı tarzda üretilmektedir. Oyuncu oyunda kaldığı sürece oyun devam etmektedir. Ancak bazı oyunlar belirli bir sona sahiptir. Bu durum modelde teleolojik anlamda "sonlu" olarak adlandırılmaktadır.

(19) Platform oyunlarının çok oyunculu örnekleri de bulunmaktadır. Burada tek oyunculu örnekleri ele alınmıştır, ancak model açısından sorunlu noktaların gösterilmesi açısından belirgin bir fark bulunmamaktadır.

(20) Oyunun kaydedilebilir olması oyunun oynanışı üzerinde etkilidir. Oyun kaydedilebilir olduğunda oyuncunun hata yapması durumunda oyunu kaldığ yerden yükleyerek devam etmesi mümkündür. Bu da yapılacak hatalara karşı daha toleranslı bir oyun sistemi ve oyuncu üzerinde daha az baskı anlamına gelmektedir. 
(21) Kazanım veya benzeri ödül sistemleri oyunlarda gittikçe yaygınlaşan, oyunun içsel mekanizması, anlam ve amaçlar dışında dışsal olarak bazı puanlanabilir hedefler eklenmesini içeren sistemlerdir.

\section{KAYNAKÇA}

Aarseth E (2001). Computer Game Studies, Year One, Game Studies: International Journal of Computer Game Research, 1 (1), http://www.gamestudies.org/0101/ editorial.html Erişim tarihi: 20.3.2015

Aarseth E (2003) Playing Research: Methodological Approaches to Game Analysis. Computer Game Theory Compendium, G. Calleja (Der.), Güz 2007, IT University of Copenhagen

Aarseth E, Smedstad S M ve Sunnana L (2003) A Multidimensional Typology of Games. Digra 2003 Conference Proceedings, Utrecht University, 48-53

Akgündüz H, Oral B ve Avanoğlu Y (2006) Bilgisayar Oyunları ve İnternet Sitelerinde Sanal Şiddet Öğelerinin Değerlendirilmesi, Milli Eğitim Dergisi, Sayı 171, Yaz 2006, 67-83

Armorgames (2014) The Company of Myself, Oyun Sayfas1, http://armorgames. com/play/4918/the-company-of-myself, Erişim tarihi: 13.11.2014

Bronkhorst Q (2012) Games vs. Movies: Who wins?, http://businesstech.co.za/ news/general/19901/games-vs-movies-who-wins/ Erişim Tarihi: 20.3.2015

Dahlskog S Kamstrup A Aarseth E (2009) Mapping the Game Landscape: Locating Genres Using Functional Classification, Breaking New Ground: Innovation in Games, Play and Theory, Digra 2009 Proceedings, http://dspace.mah.se/dspace/bitstream/handle/2043/12205/09287-47544.pdf?sequ ence $=2$ Erişim tarihi: 13.11.2014

Çakır H (2013) Bilgisayar Oyunlarına İlişkin Ailelerin Görüşleri ve Öğrenci Üzerindeki Etkilerinin Belirlenmesi, Mersin Üniversitesi Eğitim Fakültesi Dergisi, Cilt 9, Sayı 2. 138-150

Demirbaş Y (2008) Bir İletişim Formu Olarak Bilgisayar Oyunlarında "Auteur Oyun" Kuramı, Yüksek Lisans Tezi, Marmara Üniversitesi.

Elverdam C ve Aarseth E (2007) Game Classification \& Game Design: Construction Through Critical Analysis, Games and Culture, Cilt 2, Sayı 1, 3-22

Fencott C Clay J Lockyer M ve Massey P (2012) Game Invaders: The Theory and Understanding of Computer Games, New Jersey: John Wiley \& Sons

İnal Y ve Kiraz E (2008) Bilgisayar Oyunları İdeoloji İçerir Mi?,Türk Eğitim Bilimleri Dergisi, 6( 3), 523-544

Jarvinen A (2009) Games Without Frontiers: Methods for Game Studies and Design, VDM Verlag, http://ocw.metu.edu.tr/pluginfile.php/4468/mod_resource/ 
Dijital Oyunlara "Oyun Türü” Yaklaşımlarının Sorunları...

content/0/ceit706/week3_new/AkiJarvinen_Dissertation.pdf _Erişim tarihi: 13.11.2014

Juul J (2005) Half-Real: Video Games Between Real Rules and Fictional Worlds, MIT Pres.

Juul J (2010) A Casual Revolution, MIT Pres.

Karaaslan İ A (2015) Dijital Oyunlar ve Dijital Şiddet Farkındalığı: Ebeveyn ve Çocuklar Üzerinde Yapılan Karşılaştırmalı Bir Analiz. Uluslararası Sosyal Araştırmalar Dergisi, 8 (36), 806-818

Kongregate (2014) Immortall, Oyun Sayfası Okuyucu Yorumları, http://www. kongregate.com/games/Pixelante/immortall?acomplete=immortall Erişim Tarihi: 13.11.2014

Maliet S ve Meyer G (2005) The History of The Video Game, Hankbook of Computer Game Studies, J Raessens ve J Goldstein (Ed.), Cambridge ve London: MIT Press, 23-45

Parker F (2013) An Art World for Artgames. Loading: The Journal of the Canadian Game Studies Association, 7(11), 41-60

Schell J (2008) The Art of Game Design: A Book of Lenses. Burlington: Morgan Kaufmann Publishers

Tüker Ç (2014) Video Oyunları Bir Sanat Formu Olabilir mi?, Saraydan Sokağa Oyun, F Özyürek ve G Özturanlı (Ed.), İstanbul: Kabalcı Yayınevi, 179-198

Wolf M J P (2001) Genre and the Video Game,The Medium of the Videogame, M J P Wolf (Ed.), University of Texas Press, 113-134

Zimmerman E ve Salen K (2004) Rules of Play: Game Design Fundamentals. Cambridge ve London: MIT Press

\section{DIJITTAL OYUNLAR (LUDOGRAFI)}

Braid (2008)

Call of Duty (2003)

Crayon Physics (2008)

Diablo (1996)

Immortall (2010)

Lemmings (1991)

Loved(2010)

Neverwinter Nights (2002)

Pac-Man (1980) 
Selçuk İletişim, 2015, 9 (1): 363-387

Simcity (1989)

Spacewar (1960)

Starcraft (1998)

Super Mario Bros. (1985)

Tetris (1984)

The Company of Myself (2009)

Time Kufc (2009)

World of Warcraft (2004)

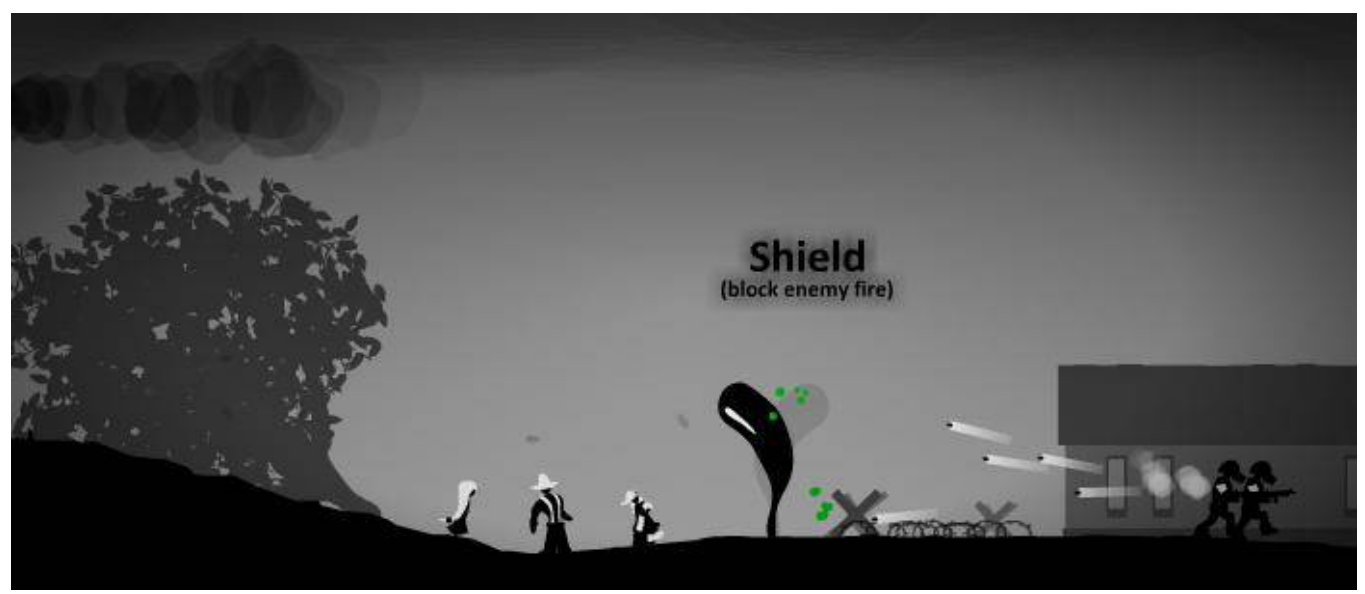

Immortall, 2010

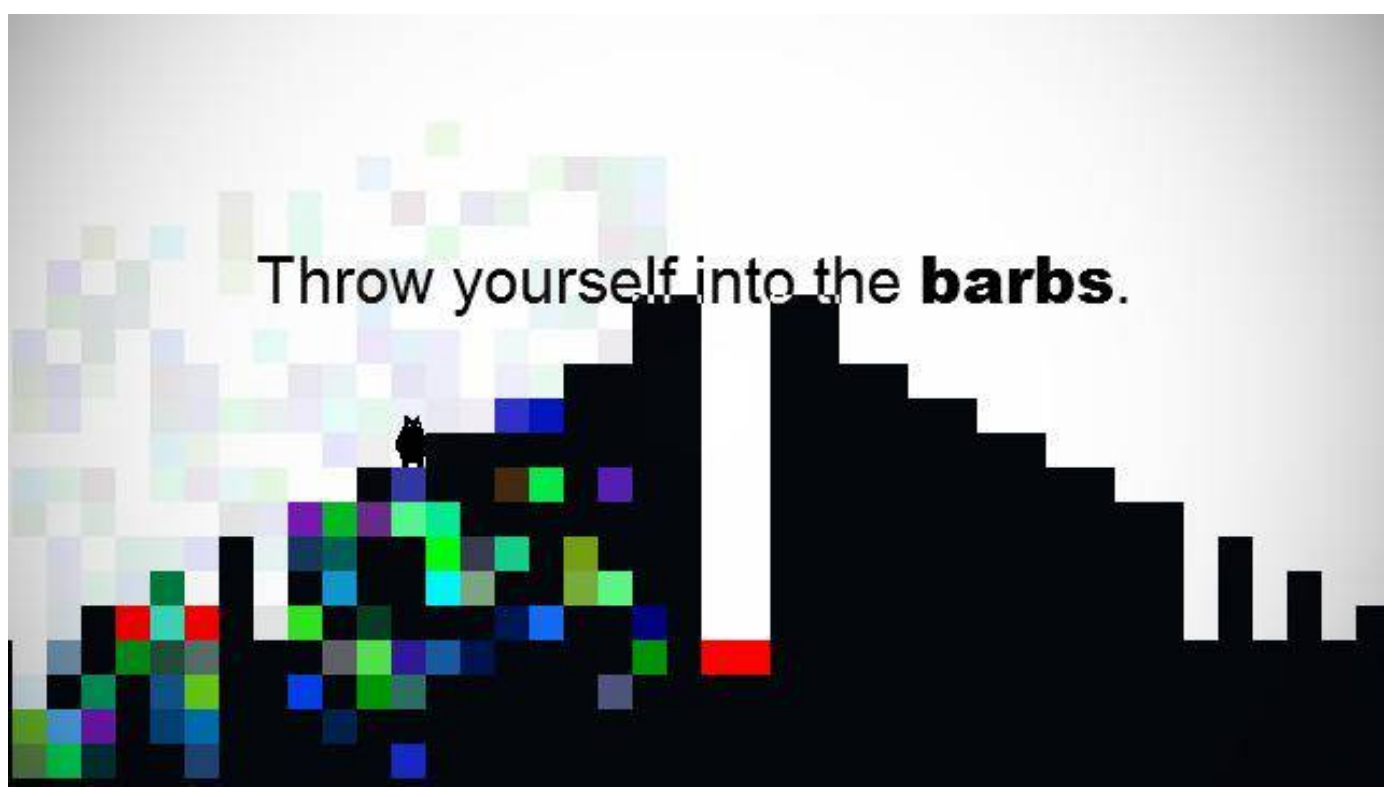

Loved, 2010 
Dijital Oyunlara “Oyun Türü" Yaklaşımlarının Sorunları...

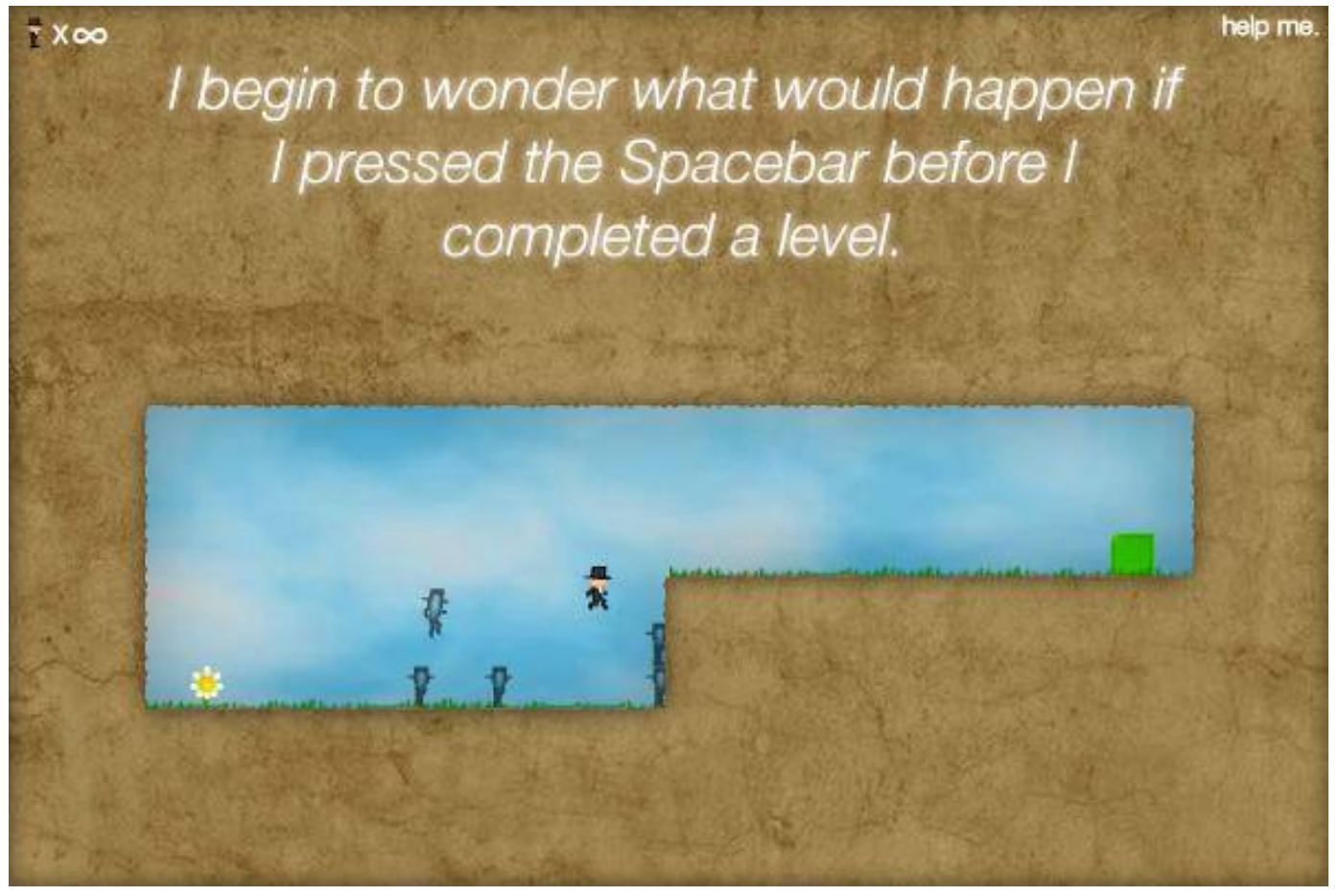

The Company of Myself, 2009

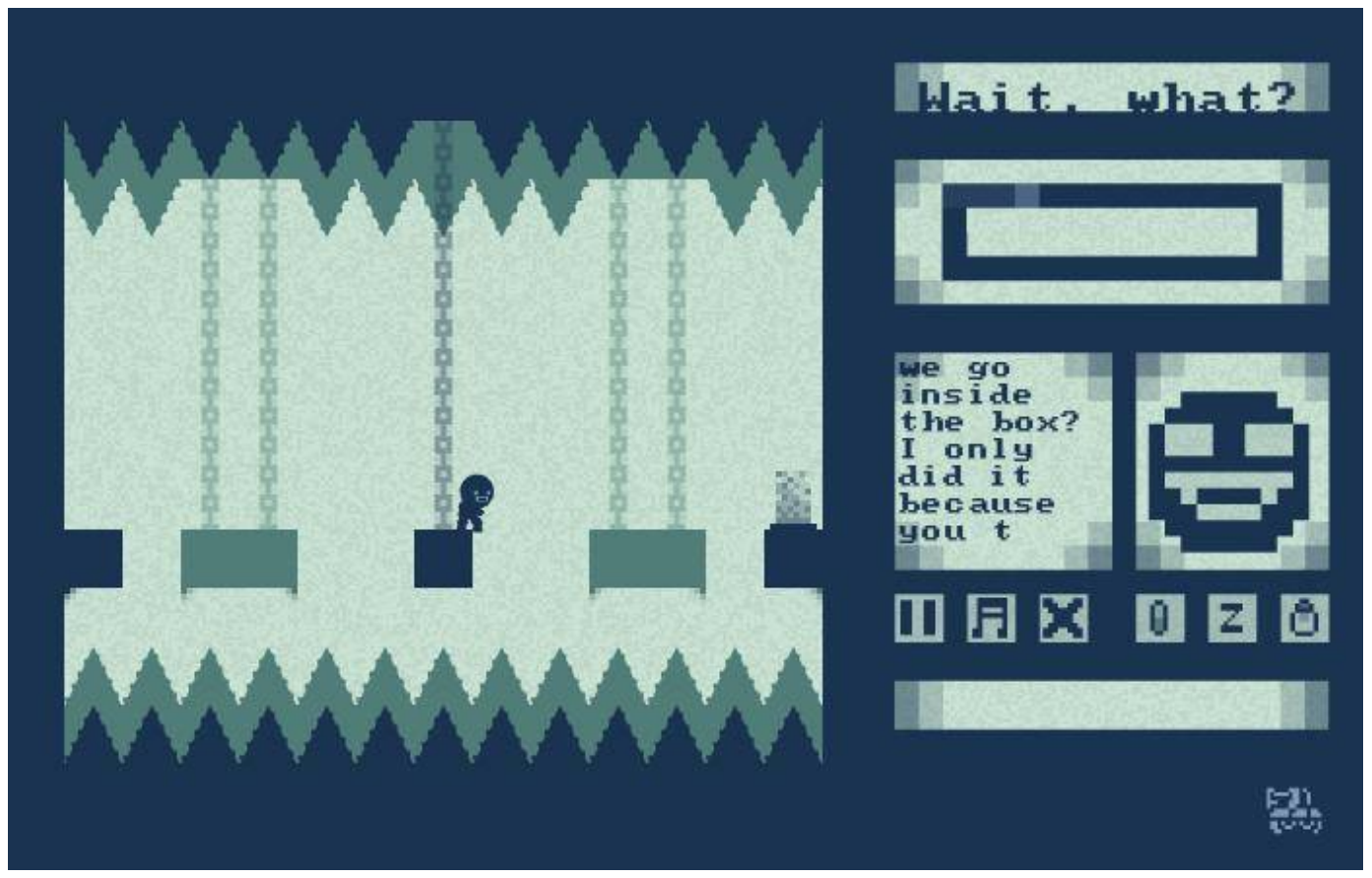

Time Kufc, 2009 